\title{
Using Granger Causality to Determine Interconnectedness in Unlisted Banking Markets
}

\author{
Kristine Petrovska \\ University of Latvia
}

\begin{abstract}
The proposed model allows to identify the interconnectedness of the banking sector where banks are nonlisted by using causal relationships (direct and indirect) between bank performance indicators. Model was applied to three separate banking markets in Baltics for time period 2014-2018. The results show that least interconnected banking sector is in Lithuania, followed by averagely interconnected Estonian market and highly interconnected Latvian banking market. Model was also able to distinguish bilateral bank pairs with no interconnectedness. This study shows that interconnectedness tests should be based on various performance indicators as banks are able to herd through various channels.
\end{abstract}

Keywords: Network Relations Theory, European Financial Markets, Interconnectedness, Causal Relations, Systemic Risk

\section{INTRODUCTION}

Systemic risk was the main reason for last global financial crisis that exposed regulators, bankers and politicians towards the inability to manage and oversee the systemic risk. According to a study done in 2013 the approximate losses from average banking crisis amount up to $23 \%$ of GDP, with 2011 crisis in Latvia amounting up to 100\% of potential GDP (Peydro, Laeven and Freixas, 2015; p.29, 117). The crisis forced regulators and policy makers to take unprecedented measures like capital purchase program, setting additional capital buffers and introducing new rules for derivative business. The macroprudential policy emerged as a new supervisory field.

Ability to detect and evaluate interconnectedness in the banking system has been one of the key issues when evaluating systemic risk. Other aspects attributable to the systemic risk are the largeness of the bank (too big to fail), its complexity (Banulescu and Dumitrescu, 2015) or uniqueness in performing a crucial function for the market or state. With ever increasing globalization, free capital movement and unified pan-European regulation, banking markets in Central and Eastern Europe have experienced rapid changes that particularly influence interconnectedness side of the systemic risk.

Banking markets in the Baltics still remain privately owned, as market share of listed commercial banks in the region remain low - from $0 \%$ in Latvia, to $7 \%$ in Estonia and $8 \%$ in Lithuania (as per author's calculation based on national stock exchange's database on listed banks, bank financial reports and European Central Bank National account statistics on bank balance sheets (assets and capital \& reserves)).

Therefore, the common tools to assess interconnectivity and systemic risk are un-applicable as for input data they use either changes of the price of the share (and similar traded assets) or loans between the 
banks that is classified information and available only to the Regulator. Also a study done in 2013 regarding Lithuanian banking sector stresses the need to model the risk of contagion and systemic risk at large but the study itself fails to model interconnectivity stating the need for confidential information and balance sheet data (Gudelytė and Navickienè, 2013).

The aim of this research is to propose a novel method, by using causal relationships (direct and indirect) between bank performance indicator changes to identify the interconnectedness of the banking sector where banks are non-listed. The method allows to identify leaders and followers of the market, therefore, fulfilling the need to distinguish too-interconnected-to-fail banks. Method was applied to three separate banking markets in Baltics - Estonia, Latvia and Lithuania for time period 2014-2018. The results show that least interconnected banking sector is in Lithuania, followed by averagely interconnected Estonian market and highly interconnected Latvian banking market. So called Nordic subsidiary banks are distanced from the market in Latvia but are central in Estonia. Due to strong causal relations between banks, leaders and mimics can be distinguished. One of the main conclusions of this research is that in the banking sectors where there are less than 10 banks present, Granger causality method is not the first-best method to identify interconnectedness.

The paper is organized as follows - next section sets base for theoretical framework, followed by section that explains the main features of the banking sectors in the Baltics. Later on, data and methodology used is being explained, followed by presentation and discussion of results and conclusion drawn.

\section{LITERATURE REVIEW}

Recent developments in evaluation of the systemic risk have been focused on a single bank's contribution to overall systemwide failure as a systemic risk (among others, Acharya, Engle and Richardson, 2012), losses being expressed through joint probabilities of major losses (5\%) by lost market value and subsequent induced market freezes.

Due to progress in the systemic risk literature, several aspects of systemic risk have already been proposed, namely, interconnectivity of the banks, expected capital shortfall of the bank in a crisis, the probability of a crisis and real social costs of a crisis per dollar of capital shortage (Acharya, Engle and Richardson, 2012), (Petrovska, 2018).

This research follows the Bank for International Settlements definition of interdependency ("A Glossary of Terms Used in Payments and Settlement Systems', 2016), meaning, that interconnections between banks are based on direct and indirect relationships arising from the activities of large financial institutions and broader commonalities. Interdependency term also covers the systemic risk aspect - that smoothness of functioning of a single bank is dependent on functioning of the other banks. What is an important regard is that interconnectedness is not only direct, that is, through direct interbank loans or payments, but also indirect. Indirect interconnectedness can be purposive - by actually mimicking other bank's business strategy, loan portfolio (Acharya and Yorulmazer, 2008) - and unconscious - mimicking other bank unknowingly.

Regulators in the EU, as they receive the information of interbank loans between banks (Regulation 2013/575/EU, 2013), should have a decent understanding of the direct interconnectedness, even if this information is not public knowledge. However, indirect interconnectedness is still a tough nut to crack. A way to crack it, is to model a network of interdependencies, known as networks.

One of the first to develop network theory for the banks was Franklin Allen and Douglas Gale (Allen Franklin; Gale Douglas, 2000), where they define the connectivity of the banks in the financial network (and its formation) as a key to financial contagion and the resulting systemic risk. They state that due to bilateral direct and indirect relationships between banks, it is of key importance to map these relationships to further understand the propagation of shocks. However, the evaluation of the interconnectivity is still problematic and methodology to quantify interconnectedness is still scarce, as stressed in Rodriguez-Moreno and Pena (Rodriguez-Moreno and Peña, 2013). Even scarcer is the 
literature on interconnectivity between banks that are not publicly listed. And such markets are the Baltics, to which the model developed will be applied to.

This research proposes an updated approach of Billio (Billio et al., 2012), using Granger causality to focus on the interconnectivity side of the systemic risk and the model developed here is applicable to markets where banks are not publicly listed (or their debt instruments).

Up until now Granger causality has been used mainly in macroeconomic perspective to identify causal relationships between economic variables, for example, Chen, Cheng and Cheng find that changes in earnings of stock companies do cause future returns, but only in times of no bubbles (Chen, Cheng and Cheng, 2009). Kaul and Kayacetin in their 2017 paper find out that an increase in difference between large and small cap stock order flows, strongly and negatively forecasts output growth and interest rates in the US, their test period being from 1983 to 2006 (Kaul and Kayacetin, 2017). Just recently Granger causality was used to determine that only in high-income economies reverse causality between economic growth and equity market development is expressed, while in trapped middle-income economies banking system development and inflation are dually interrelated (Yang, 2019).

However, Granger causality as a method to identify interrelations between variables in the banking sector is a relatively new approach. Fiordelisi, Marques-Ibanez and Molyneux by using data set of banks from 26 EU countries for period 1995-2007, identify the relationship between bank efficiency and capital, revealing that lower efficiency causes higher risk, while more efficient banks later on become better capitalized (Fiordelisi, Marques-Ibanez and Molyneux, 2011). Rodriguez-Moreno and Pena, however, use Granger causality to determine whether largest US bank holdings of specific derivative instruments increase that bank's contributions to overall systemic risk. They find that this is true only in several types of derivatives, like foreign exchange and credit derivatives (Rodriguez-Moreno and Peña, 2013). The research conducted in 2016, by using Granger causality shows that bi-directional causality exists between various interbank money market rate spreads (LIBOR-OIS spread, euro fixed-float OIS swap rate and the three-month US-German bond spread) (Eross, Urquhart and Wolfe, 2016).

Only during the European debt crisis, Billio et al. introduced Granger causality into the systemic risk theory to identify bilateral causal relationships between banks and insurance sectors and to determine interconnectedness and spill-over mechanism between different market participants (Billio et al., 2012). Following Billio et al. approach to use Granger causality to find interconnectedness, a study in 2016 for China, finds that negative shocks in the insurance and banking sectors are bi-directional, while positive shocks do not exhibit the same relations; and that negative shocks in the insurance sector cause opposite direction of shocks in the banking sector (Pan, Guo and Jing, 2016).

However, Billio et al. used only monthly returns as input data, therefore, scratching only the surface of the true interconnectedness, as it lies not only on assets side, but also between loan portfolios, liquidity and leverage preferences. Besides banks in distress, may lack the incentives to disclose their losses, therefore, setting biased input data.

Following herding theory in the banking, that was established by Acharya \& Yorulmazer (Acharya and Yorulmazer, 2008), it is of uttermost importance to find banking sector leaders and followers or mimics. To expand the ground-breaking ideas of Acharya \& Yorulmazer, herding must be identified not only in the form of correlated loan portfolios (investment decisions) but also in other business strategy decisions, like leverage and liquidity management. And incentives for herding should be penalized either by market or Regulator (Petrovska and Bojāre, 2018).

Deliberate or oblivious herding in asset returns means that a bank follows a business strategy of another bank. This is rational, as according to Acharya and Yorulmazer increased correlation in loan returns of banks increases their joint survivorship, when being in distressed state as Lender of Last Resort (usually the Central Bank) will be forced to support all these banks as not to allow for systemic crash (Acharya and Yorulmazer, 2002). As the leaders have extra bargaining and market power, they should be considered as systematically important banks that need additional regulatory supervision.

Granger causal networks in the banking sector are resource-consuming to build, other methods to identify interconnectivity and systemic risk propagation at large are preferred where optional, for example Conditional Value-at-Risk (Adrian and Brunnermeier, 2016), Systemic Expected Shortfall (Acharya et 
al., 2017), Extreme-Value analysis (De Jonghe, 2010), SRISK (Brownlees and Engle, 2017) Distress Insurance premium based on CDS (Huang, Zhou and Zhu, 2012) or Systemic Contingent Claims Analysis (Jobst and Gray, 2013).

However, these methods are not applicable in the Baltic states, mostly due to banks being not publicly listed (or their debt instruments).

\section{BANKING SECTORS IN THE BALTICS}

Baltic states regained their independence in early 1990 due to the collapse of the USSR. Owing to very fast transformation from planned economy to market economy, also banking sector flourished, at least the number of banking licenses issued did. In Estonia several banks even got listed in the local Stock Exchange that amounted up to $60 \%$ of the total market capitalization (Liuhto et al., 2007).

The first collapse of banking sector in all three states was seen during 1998 Russian crisis, where the number of active and performing banks decreased dramatically. Early 2000-s marked the era of takeovers by large Scandinavian banks - SEB, Swedbank, Nordea, DnB. In Lithuania - also German and Finnish banks (Čičinskas and Šadžius, 2006). While years after 2010s marked the years where banks were forced to close down by regulators due to money laundering claims or possible fraudulent activities by bank owners: in Lithuania - Snoras bank in 2011 and Ukio bank in 2013 (Mažylis and UnikaiteJakuntavičiene, 2014); in Latvia - Latvijas Krājbanka in 2011 (related to Snoras), Trasta Banka in 2014, ABLV in 2018, PNB in 2019; in Estonia - Versobank in 2018 (Versobank, 2018) and Danske's subsidiary in Estonia.

Banking sectors in all three Baltic states are highly concentrated (Kubiszewska and Balkan, 2017). Largest Scandinavian subsidiary banks have significantly great financial resources than the other - local owned banks (Rimavičiūte and Vilys, 2014). That might be the reason why banks in these countries are not publicly listed. The markets are being highly concentrated and yet fragile, as customers are fearsome about their investments due to fresh memory of bank bankruptcies in 1990-s (Skvarciany et al., 2018).

Currently there are 7 banks in Lithuania that hold the license (Banking sector, 2019), 13+1 banks in Latvia (PNB is currently being liquidated but still hold the license) (FKTK - Market - Credit institutions Banks, 2019) and 9 in Estonia (Register of Market Participants, 2019).

\section{DATA AND METHODOLOGY}

To model interconnectivity network, bank performance indicators are used as input data. As reporting standards differ between countries, there are slight differences between the input ratios, see Table no. 1. Input data were acquired from bank webpages where they must publicly issue quarterly financial reports.

\section{TABLE 1 \\ INPUT DATA FOR GRANGER CAUSALITY}

\begin{tabular}{|l|l|l|}
\hline Estonia & Latvia & Lithuania \\
\hline Equity multiplier & Equity multiplier & Equity multiplier \\
\hline Return on assets & Return on assets & Return on assets \\
\hline Cash balance & Short term liquidity & Short term liquidity \\
\hline Tier 1 capital & Capital adequacy & \\
\hline Loans to customers & & Loans to customers \\
\hline
\end{tabular}

Source: Author's developed based on available data

Due to Lithuania's Regulator's request major banks from 2015 had to increase their liquidity, therefore, they did not report exact numbers during periods 2015-2016. 


\section{Ratios}

In this study financial indicators for each bank in question were used as an input for Granger causality tests. These performance indicators are based on CAMELS type of evaluation of the soundness of the banks but are revised based on the data that banks are enforced to publicly disclose. For example, in Lithuania, banks only publish balance sheet data. The selection was also based on individual banks' health indicators, as defined by Ong (Ong, Jeasakul and Kwoh, 2013).

The calculation of equity multiplier was followed by Ross et al (Ross, Westerfield, Jaffe, Jordan, 2011) while the calculation of other ratios was followed by Ong (Ong, Jeasakul and Kwoh, 2013).

First ratio is equity multiplier (EM). The calculation was done according to equation 1.

Equity multiplier $=\frac{\text { total assets }}{\text { total } \text { equity }}$

The higher the equity multiplier, the riskier banking operations are.

The next ratio is return on assets (ROA). The calculation was done according to equation 2.

Return on assets $=\frac{\text { total profit after taxes }}{\text { total assets }}$

The higher the ratio, the bank is performing better. However, if bank has excessive returns it might develop traits of possible instability. For Danske - difference in total profits is used, as total assets were not disclosed since 2015.

The next ratio is short term liquidity (LIQ) ratio. The calculation was done according to equation 3.

Liquidity ratio $=\frac{\text { current assets with maturity up until one month }}{\text { current liabilities with maturity up until one month }}$

This ratio shows how well bank is able to meet its short-term obligations - the higher the ratio the more liquid (safe) the bank is. As in 2018 the regulatory requirements dramatically changed for the reported bank liquidity, the timeframe for this ratio was only from 01-01-2014 till 31-12-2017.

Last ratio is capital adequacy $(\mathbf{C A})$ ratio. The calculation was done according to equation 4.

Capital adequacy $=\frac{\text { total capital }}{\text { risk weighted assets }}$

This ratio shows how well capitalized the bank is - higher the ratio the more capitalized the bank is (and is to be considered safer).

Even though the local Regulator might set some minimum requirements for CA and LIQ, the research uses the changes in the ratios as input data for Granger causality network, therefore omitting possible biases.

The Loans indicator was taken from the balance sheet as the loans to customer at the end of the reporting period. As in the model first differences of the variable are used, this indicator shows how fast is the loan portfolio growing and pertaining conclusions drawn whether bank is not undertaking excessive risk and if these strategies are interrelated between banks.

The Cash balance was taken from end of period cash flow report as the end of date cash balance. Time period for the study is from 31.12.2013. till 31.12.2018. with exceptions of ABLV (till 31.12.2017.), Danske Bank in Estonia (till 31.12.2017.) and Versobank (till 31.12.2017.) as these banks ceased to hold banking licenses. These banks were added in the study as there are open claims that these banks laundered money (PRESS RELEASE: ECB determined ABLV Bank was failing or likely to fail, 2018), (List of Banks in Estonia, 2019), therefore, it is of utmost importance to see how interconnected these banks were in the local market and whether they played an important role in the local banking sector.

156 Journal of Accounting and Finance Vol. 19(9) 2019 
The banks in the sample are presented in Table no. 2 .

TABLE 2

BANKS IN THE SAMPLE

\begin{tabular}{|l|l|l|}
\hline Estonia (12) & Latvia (15) & Lithuania (6) \\
\hline Bigbank (BIG), Citadele (CIT) & ABLV, Baltic International & Citadele (CIT) (LV), Danske \\
(LV), Coop bank (COOP), & Bank (BIB), Blue Orange & Bank Lithuania, Medicinos \\
Danske bank Estonian branch & (BLUE), Citadele (CIT), & bankas (MED), SEB, Šiaulia \\
(DAN), InBank (INB), LHV & Expobank (EXPO), LPB, & bank (SIA), Swedbank \\
Bank (LHV), OP (Pohjola - & MTB, PNB, Privat bank & (SWED) \\
FIN), SEB, Svenska & (PRIVAT), Rietumu, Rigensis & \\
Handelsbanken (HAN) (SWE), & (RIG), Regionala Investiciju & \\
Swedbank (SWED), Taripank & banka (RIB), Signet, SEB, & \\
(TAR), Versobank (VER) & Swedbank (SWED) & \\
\hline
\end{tabular}

Source: Author's developed

These banks take the absolute largest part of the local banking sector. As some banks supply their services in Estonia and Lithuania without holding license there, banking group data were added to test whether foreign banks are also interdependent within the local market (Citadele, OP, Svenska Handelsbanken). There is one important market player that is missing from the sample as it is an Estonian bank whose owners are large Nordic bank and an US investment firm. However, this particular bank is not legally bound to publicly disclose any financial data for Latvian or Lithuanian subsidiary and therefore chooses not to publish the data; and it was a merger between two banks in 2018 therefore the available data timespan for study is too short. Where optional, bank and not group data are used.

\section{Stationarity}

To test Granger causality, time series must be stationary, therefore, firstly, ratios were first differenced and later on unit root test - Augmented Dickey Fuller test was applied using p lags of the dependent variable (Brooks, 2008, p.329), see equation 5.

$\Delta_{t}=\psi y_{t-1}+\sum_{i=1}^{p} \alpha_{i} \Delta_{t-1}+u_{t}$

Lag length for unit-root tests were automatically selected based on Schwarz info criterion (see equation 6) and were either 0 or 2. These tests were closely followed as in (Zheng and Song, 2018).

$S C=\frac{-2 l}{T}+n \frac{\ln T}{T}$

where $n$ is the total number of estimated parameters, $k$ is the number of endogenous variables, $T$ is the sample length, $d$ is the number of exogenous variables, and $p$ is the number of lag orders. The logarithmic likelihood value $l$ can be calculated by hypothesizing that the multivariate normal distribution is met, see equation 7.

$\left.\left.l=-\frac{T k}{2}(1+\ln 2 \pi)-\frac{T}{2} \operatorname{lndet} \frac{1}{T-m} \sum_{t} \varepsilon_{t} \varepsilon_{t}^{\prime}\right)\right)$

Even after first differencing some time series were still non-stationary, therefore, were excluded from further tests, namely: 
(1) Estonia: COOP_LOA, INB_EM, INB_CASH, LHV_ROA, LHV_EM, LHV_T1, LHV_CASH, SEB_LOA, HAN_T1;

(2) Latvia: PrivatBank_EM, RIB_EM, Swed_LIQ, Signet_LIQ, PNB_LIQ;

(3) Lithuania: DAN_ROA, DAN_EM, DAN_LIQ, MED_LIQ, SEB_LIQ, SWED_LIQ.

Second differences of these time series were stationary, but the economical meaning of such time series is lost. Stationarity and Granger causality tests were done using Eviews 7software package.

\section{Granger Causality}

Granger causality was first developed in 1969 by C.W. J. Granger to test two-variable case of causality and feedback mechanisms.

This test examines whether past changes in one variable, $X_{t}$, help to explain current changes in another variable, $Y_{t}$. If not, it can be concluded that $X_{t}$ does not Granger cause $Y_{t}$. The test is based on regression below:

$\Delta_{t}=\alpha+\sum_{i=1}^{p} \beta_{y i} \Delta_{t-i}++\sum_{i=1}^{p} \beta_{x i} \Delta_{t-i}+\varepsilon_{t}$

where $\Delta$ is the first-difference operator and $\Delta$ and $\Delta$ are stationary bank specific performance indicators (for example, $\Delta$ SWED_ROA and $\Delta$ RIB_ROA), $\mathrm{p}=18$ (14 for liquidity), $\mathrm{i}=2$ as 2 is the optimal lag selection based on Schwarz info criterion and during two time periods the influence of a particular bank should have been expressed fully.

Null hypothesis that $X_{t}$ does not Granger cause $Y_{t}$ is rejected if coefficients $\beta_{x i}$ are jointly significant based on the standard F-test, similar to Rodriguez-Moreno and Pena (Rodríguez-Moreno and Pena, 2013).

The significance of causality is classified in 3 intervals, namely:

$\mathrm{p}<0.05$ - strong causality;

$0.5<\mathrm{p}<0.1$ - average causality;

$0.1<\mathrm{p}<0.15$ - weak causality.

Significance levels have also been ranked in Oet, Bianco, Gramlich \& Ong (Oet et al., 2013). However, they use significance level up to $20 \%$.

Nevertheless the shortness of the sample length-size in this research, C.W.J. Granger states that if sampling period is too long then details of causality cannot be distinguished (Granger, 1969).

Acharya, Engle \& Richardson do raise the awareness that Granger causality tests cannot be correctly interpreted unless all the shocks are considered at the same time (Acharya, Engle and Richardson, 2012). However, as the sample consists of all the banks in the market (except the one that was exclude from study due to merger), this issue is offset.

\section{Network}

After calculating all the pairwise Granger causality tests for all bank performance indicators, positive Granger causality were classified within 3 previously mentioned intervals. Strong causality was given the thickest line $(2.25 \mathrm{pt})$ to emphasize the strong linkage, average line $(1 \mathrm{pt})$ was attributed to average causality and the thinnest line $(0.5 \mathrm{pt})$ was attributed to weak causality. Each line was also attributed a different color in which performance indicator the connectedness was found. Legend is shown in Table no. 3 . 
TABLE 3

LEGEND FOR THE INTERCONNECTEDNESS

\begin{tabular}{|c|c|c|c|c|c|c|}
\hline Significance & Figure & Indicator & Figure & Indicator & Figure & Indicator \\
\hline $\mathrm{p}<0.05$ & $\Longrightarrow$ & \multirow{3}{*}{ ROA } & $\longrightarrow$ & \multirow{3}{*}{ LOA } & $\rightarrow$ & \multirow{3}{*}{$\begin{array}{l}\mathrm{LIQ/} \\
\mathrm{CASH}\end{array}$} \\
\hline $0.5<\mathrm{p}<0.1$ & $\longrightarrow$ & & $\rightarrow$ & & $\rightarrow$ & \\
\hline $0.1<\mathrm{p}<0.15$ & $\longrightarrow$ & & $\rightarrow$ & & $\rightarrow$ & \\
\hline $\mathrm{p}<0.05$ & $\rightarrow$ & \multirow{3}{*}{ EM } & $\longrightarrow$ & \multirow{3}{*}{$\begin{array}{l}\text { T1 } \\
\text { capital/ } \\
\text { capital } \\
\text { adequacy }\end{array}$} & & \\
\hline $0.5<p<0.1$ & $\rightarrow$ & & $\longrightarrow$ & & & \\
\hline $0.1<\mathrm{p}<0.15$ & $\rightarrow$ & & & & & \\
\hline
\end{tabular}

\section{RESULTS}

After conducting Granger causality tests on banking performance indicators, it has been found that Estonian and Latvian market is quite interconnected, while the Granger causality tests clearly fails to acknowledge interconnectedness in the Lithuanian banking market. Regarding Lithuanian market there are two possible explanations - either test is not applicable to the market where there are only small number of banks present or banks in Lithuania are so independent from one another that they simply are not interconnected. When changing liquidity indicator with cash balances, the results did not improve.

There are total 60 Granger-causal relations between banks in Estonia, 109 in Latvia and 12 in Lithuania. It is important to note that 27 in Estonia and 35 in Latvia bank pairs showed no interconnectedness between them, suggesting that these banks do operate completely independently.

Banks in Estonia are more interconnected through EM (18), LOA (15), ROA (11), CASH (9) indicators, while banks in Latvia through ROA (37), CA (31). The indicator through which banks show the least interconnectedness is T1 (7) in Estonia and LIQ (20) and EM (21) in Latvia.

This study clearly shows that testing for interconnectedness at least several indicators are needed to be tested, not only ROA, as bank strategy might depend on herding through other channels, like liquidity management, loan portfolio or capital management.

The overall interconnectedness of the banking sectors in the Baltic States can be seen in Figures 1-3. 
FIGURE 1

INTERCONNECTEDNESS OF THE ESTONIAN BANKING MARKET, YEARS 2014-2018

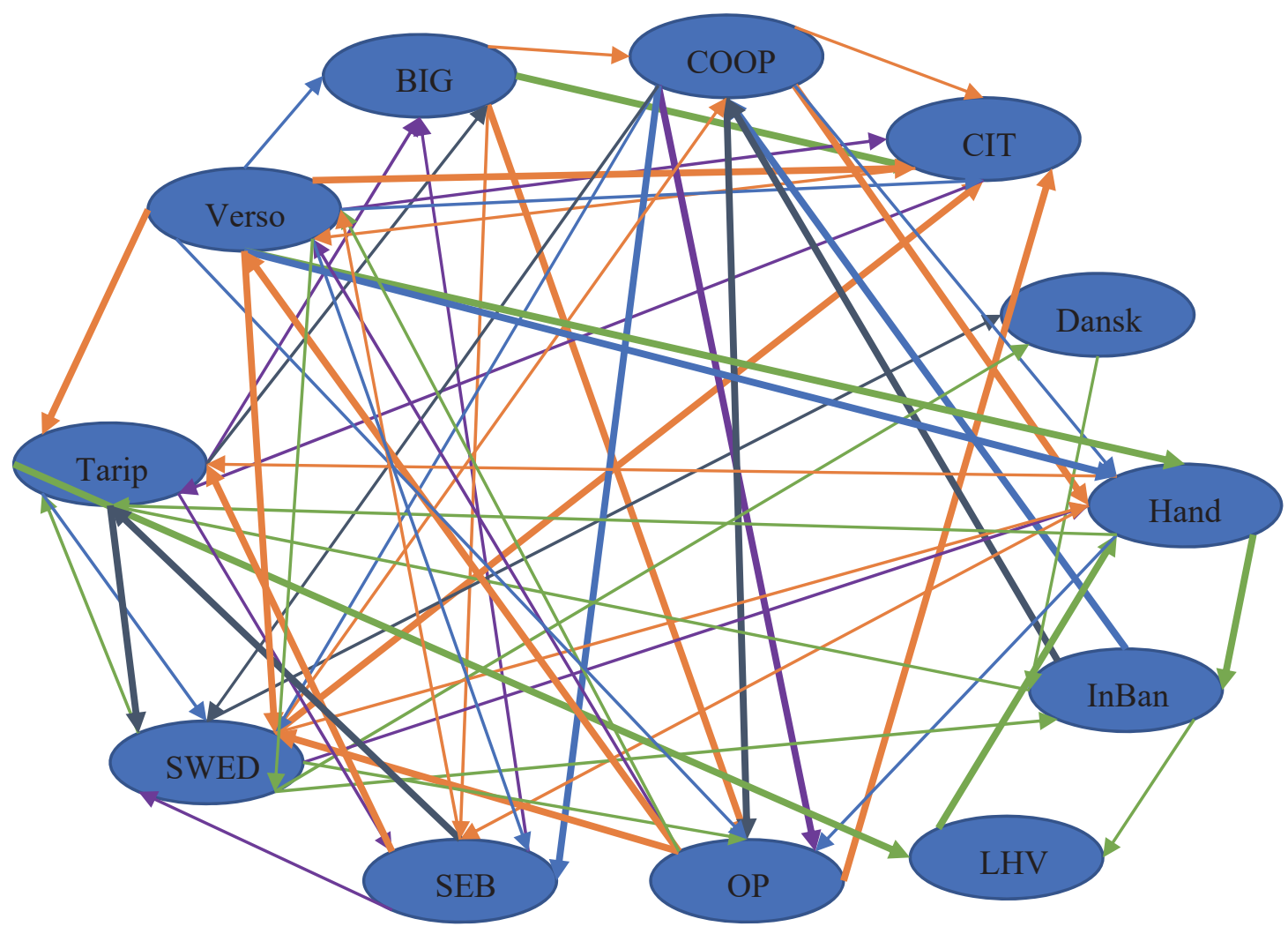

The leaders of Estonian market are Verso and SWED \& COOP as they originate 11 and eight causal relations each. The list is followed by TAR with six, SEB, OP each with five and BIG, HAND, INB each with five. The most susceptible mimics or followers are SEB and SWED with eight causal relations, followed by CIT, HAND with seven and OP with 6. 


\section{FIGURE 2}

\section{INTERCONNECTEDNESS OF THE LATVIAN BANKING MARKET, YEARS 2014-2018}

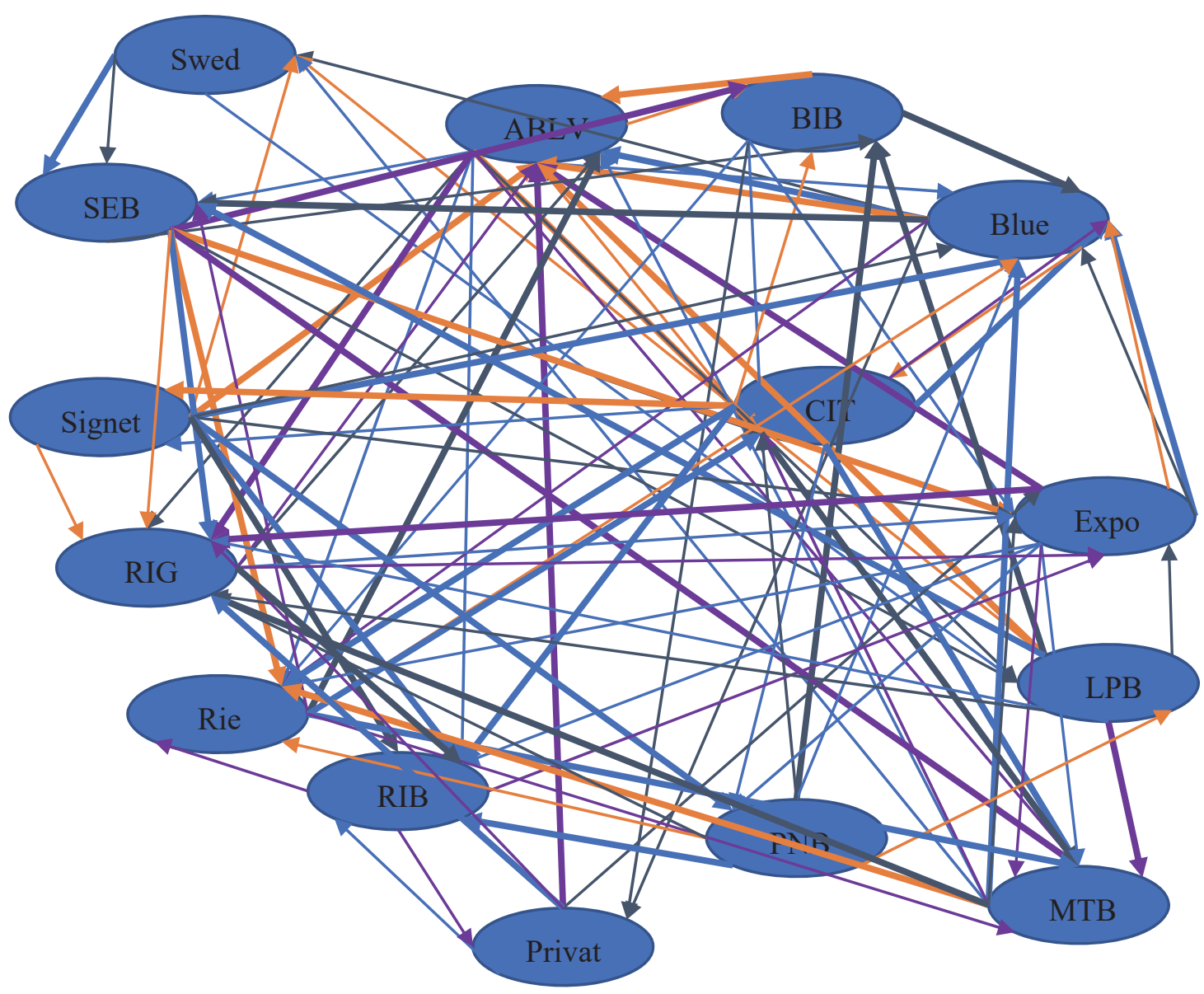

The leaders of Latvian market are CIT with 11 originated causal relations, followed by ABLV and EXPO as they each originate 10 causal relations, Signet originates nine causal relations, LPB, SEB each eight. The most susceptible mimics or followers are ABLV, BLUE and RIG each of which picks effect from other banks in 12 cases, followed by EXPO, MTB with nine. 
FIGURE 3

INTERCONNECTEDNESS OF THE LITHUANIAN BANKING MARKET, YEARS 2014-2018

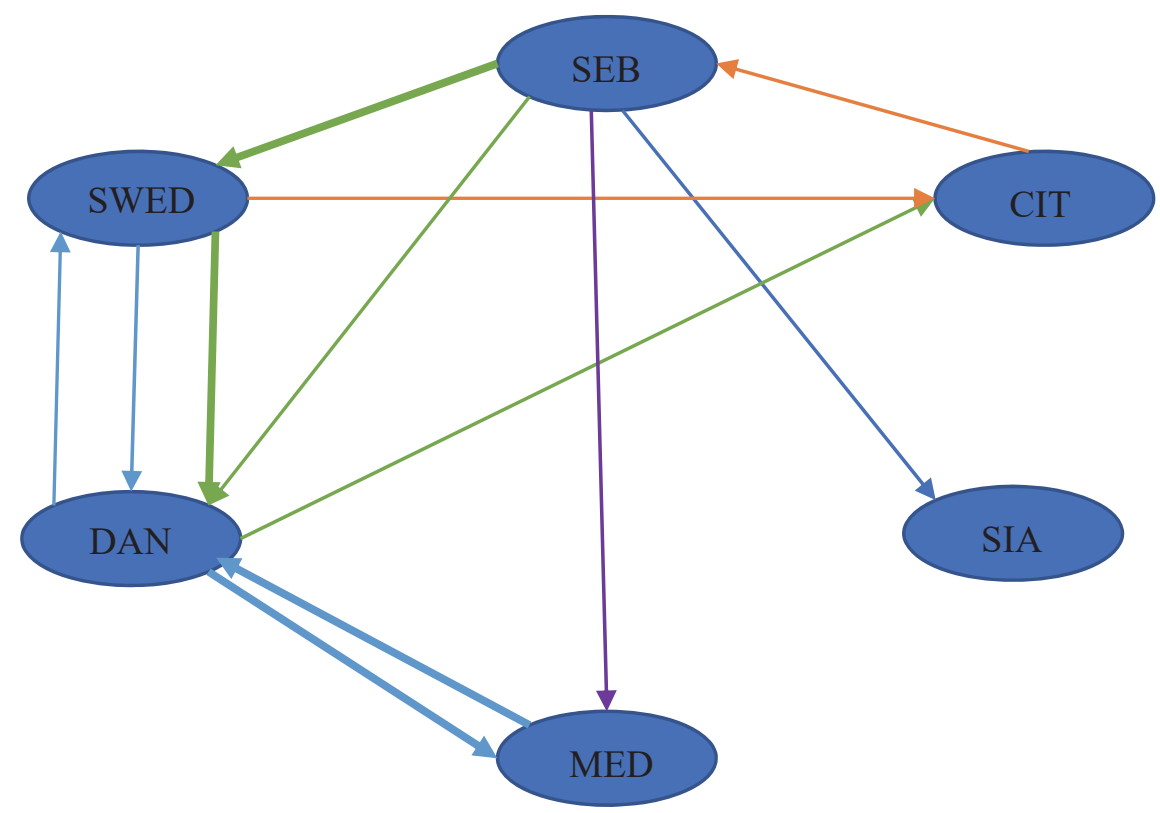

So called Nordic banks in Latvia are somehow distant while in Estonia they are in the center. Even though Danske seems to be distanced, it is mainly due to the lack of stationarity of the data as well as bank not disclosing necessary data.

\section{DISCUSSION}

Apparently, the developed method for testing interconnectedness in the market is only applicable to markets where the number of banks present exceed the number of 10. Even though years 2014-2018 marked not only the adoption of Basel III accords and introduction of macroprudential supervision (Directive 2013/36/EU, 2013), but also increased anti-money-laundering requirements, banks still managed to follow their business strategies, as the input data were not so called "white noise" but expressed trends. Even though Latvian banking sector has only few more banks present than Estonia, it is way more interconnected.

A drawback of this method is that for short samples (with less than 10 datapoints) very rarely does the interconnectedness is exposed. Besides if there are data missing from the sample, then Granger test only uses the most recent time-series. Also, interpolation to get the missing point is not possible, as it would offset the trend that Granger causality is trying to detect.

\section{CONCLUSIONS}

This study has shown a pioneering method to detect interconnectedness between banking sector participants in a way that is applicable to markets where banks are not publicly listed, as is the case for Central and Eastern Europe countries.

To test Granger causal relations, it is not enough to use only ROA as an input variable, as interconnectedness and bank herding can happen in other business strategy channels, like capital adequacy, liquidity management or loan portfolios. This has also been concluded from the study done in this research. As input variables for Granger-causal relations are first differences of the numbers and not 
absolute numbers, biases that banks need to follow national Regulator set standards are offset as banks can freely choose the conversion level.

Overall, it can be concluded that Granger causality-based networks are not fully applicable to markets where the number of market participants is low, like in Lithuania and search for appropriate method should be continued on such cases. However, this method shows prominent results in both - Estonia and Latvia, where the level of interconnectedness between market participants seems average (in Estonia) and high in Latvia.

\section{ACKNOWLEDGEMENT}

This work was supported by the Timerman Scholarship for Competitiveness Studies in Social Sciences administered by Fund of University of Latvia [grant number SL-1045-01/2018].

\section{REFERENCES}

A Glossary of Terms Used in Payments and Settlement Systems. (2016). Bank for International Settlements, p. 18. Retrieved from https://www.bis.org/dcms/glossary/glossary.pdf?scope=CPMI\&base=term.

Acharya, V. V., et al. (2017). Measuring systemic risk. Review of Financial Studies, 30(1), 2-47. doi: $10.1093 / \mathrm{rfs} / \mathrm{hhw} 088$.

Acharya, V. V., Engle, R., \& Richardson, M. (2012). Capital Shortfall: A New Approach to Ranking and Regulating Systemic Risks. American Economic Review: Papers \& Proceedings, 102(3), 59-64. doi: http://dx.doi.org/10.1257/aer.102.3.59.

Acharya, V. V., \& Yorulmazer, T. (2002). Information Contagion and Inter-Bank Correlation in a Theory Of Systemic Risk, SSRN. London. doi: 10.2139/ssrn.365940.

Acharya, V. V., \& Yorulmazer, T. (2008). Information Contagion and Bank Herding. Journal of Money, Credit and Banking, 40(1), 215-231. Retrieved from https://www.jstor.org/stable/25096246

Adrian, T., \& Brunnermeier, M. K. (2016). CoVaR. American Economic Review, 106(7), 1705-1741. doi: http://dx.doi.org/10.1257/aer.20120555

Allen, F., \& Gale, D. (2000). Financial Contagion. Journal Of Political Economy, 108(1), 1-33.

Banking sector. (2019). Lietuvos Bankas. Retrieved from https://www.lb.lt/en/fs-banks.

Banulescu, G. D., \& Dumitrescu, E. I. (2015). Which are the SIFIs? A Component Expected Shortfall approach to systemic risk. Journal of Banking and Finance, Elsevier B.V., 50, 575-588. doi: 10.1016/j.jbankfin.2014.01.037.

Billio, M., et al. (2012). Econometric measures of connectedness and systemic risk in the finance and insurance sectors. Journal of Financial Economics, Elsevier, 104(3), 535-559. doi: 10.1016/j.jfineco.2011.12.010.

Brooks, C. (2008). Introductory Econometrics for Finance. Fifth prin. Cambridge: Cambridge University Press.

Brownlees, C., \& Engle, R. F. (2017). SRISK: A Conditional Capital Shortfall Measure of Systemic Risk. The Review of Financial Studies, 30(1), 48-79. doi: 10.1093/rfs/hhw060.

Chen, A. S., Cheng, L. Y., \& Cheng, K. F. (2009). Intrinsic bubbles and Granger causality in the S\&P 500: Evidence from long-term data. Journal of Banking and Finance, 33(12), 2275-2281. doi: 10.1016/j.jbankfin.2009.06.005.

Čičinskas, J., \& Šadžius, L. (2006). Evolution of the Banking System in Lithuania: From State-owned Mono-Banks to a Modern Banking System (1988 - 2004). Ekonomika, pp. 7-20.

De Jonghe, O. (2010). Back to the basics in banking? A micro-analysis of banking system stability. Journal of Financial Intermediation, Elsevier Inc., 19(3), 387-417. doi: 10.1016/j.jfi.2009.04.001.

Directive 2013/36/EU (2013). Directive 2013/36/EU of the European Parliament and of the Council of 26 June 2013 on access to the activity of credit institutions and the prudential supervision of credit 
institutions and investment firms, amending Directive 2002/87/EC and repealing Dir'. Brussels: Official Journal of the European Union. European Parliament and the Council. Retrieved from http://data.europa.eu/eli/dir/2013/36/oj.

Eross, A., Urquhart, A., \& Wolfe, S. (2016). Journal of International Financial Markets , Institutions \& Money Liquidity risk contagion in the interbank market. Journal of International Financial Markets, Institutions \& Money, 45, 142-155. doi: 10.1016/j.intfin.2016.07.005.

European Central Bank National account statistics on bank balance sheets (assets and capital \& reserves). (n.d.). Retrieved from http://sdw.ecb.europa.eu/reports.do?node=1000003245; http://sdw.ecb.europa.eu/reports.do?node=1000003197; http://sdw.ecb.europa.eu/reports.do?node=1000003169. National Stock Exchange's database on listed banks. Bank quarterly financial reports from bank webpages.

Fiordelisi, F., Marques-Ibanez, D., \& Molyneux, P. (2011). Efficiency and risk in European banking. Journal of Banking and Finance, 35(5), 1315-1326. doi: 10.1016/j.jbankfin.2010.10.005.

FKTK - Market - Credit institutions - Banks. (2019). Financial and Capital Market Commission. Retrieved from http://www.fktk.lv/en/market/credit-institutions/banks.html

Granger, C. W. J. (1969). Investigating Causal Relations by Econometric Models and Cross-spectral Methods. Econometrica, 37(3), 424-438. doi: 10.2307/1912791.

Gudelytė, L., \& Navickienè, O. (2013). MODELLING OF SYSTEMIC RISK OF BANKING SECTOR. Social Technologies, 3(2), 359-371. doi: 10.13165/ST-13-3-2-09.

Huang, X., Zhou, H., \& Zhu, H. (2012). Assessing the systemic risk of a heterogeneous portfolio of banks during the recent financial crisis. Journal of Financial Stability, 8(3), 193-205. doi: 10.1016/j.jfs.2011.10.004.

Jobst, A. A., \& Gray, D. F. (2013). Systemic Contingent Claims Analysis: Estimating Market-Implied Systemic Risk. IMF Working Papers, 13(54), 1-92. doi: 10.5089/9781475572780.001.

Kaul, A., \& Kayacetin, N. V. (2017). Flight-to-quality, economic fundamentals, and stock returns. Journal of Banking and Finance, 80, 162-175. doi: 10.1016/j.jbankfin.2017.04.003.

Kubiszewska, K., \& Balkan, W. (2017). Banking concentration in the Baltic and Western Balkan states selected issues. Oeconomia copernicana, 8(1), 65-82. doi: 10.24136/oc.v8i1.5.

List of Banks in Estonia. (2019). Bank Directory. Retrieved from https://thebanks.eu/banks-bycountry/Estonia.

Liuhto, K., et al. (2007). Organizational and sectoral changes in transition banking : Estonian experience. Trames Journal of the Humanities and Social Sciences, 11(61/56)(2), 155-172. Retrieved from https://www.academia.edu/30027564/Organizational_and_sectoral_changes_in_transition_bankin g_Estonian_experience.

Mažylis, L., \& Unikaite-Jakuntavičiene, I. (2014). Banking System Stability and Public Security: the Cases of the Collapse of the Commercial Banks "Snoras" and "Ükio bankas" in Lithuania. Lithuanian Annual Strategic Review, 12, 275-298. doi: 10.2478/lasr-2014-0012.

Oet, M. V., et al. (2013). SAFE: An early warning system for systemic banking risk. Journal of Banking and Finance, Elsevier B.V., 37(11), 4510-4533. doi: 10.1016/j.jbankfin.2013.02.016.

Ong, L. L., Jeasakul, P., \& Kwoh, S. (2013). HEAT! A Bank Health Assessment Tool. International Monetary Fund, p. 21. doi: 10.5089/9781484385227.001.

Pan, G., Guo, J., \& Jing, Q. (2016). THE RELATIONSHIP BETWEEN INSURANCE INDUSTRY AND BANKING SECTOR IN CHINA: ASYMMETRIC GRANGER CAUSALITY TEST. Romanian Journal of Economic Forecasting, XIX(2), 114-127.

Petrovska, K. (2018). An Alternative For Detecting Systemic Risk in the Banking Sector. Principal Components Approach, in New Challenges of Economic and Business Development 2018. Riga: Faculty of Business, Management and Economics, University of Latvia, pp. 511-519. Retrieved from https://www.bvef.lu.lv/fileadmin/user_upload/lu_portal/projekti/evf_conf2018/Proceedings_2018 .pdf. 
Petrovska, K., \& Bojāre, K. (2018). Why Banks Choose to Take Excessive Risk That Leads to Dangerous Outcomes? Journal of Economics and Management Research, 7, 6-25. doi: http://doi.org/10.22364/jemr.7.01.

Peydro, J. L., Laeven, L., \& Freixas, X. (2015) Systemic risk, Crises and macroprudential regulation. MIT Press. doi: 10.1017/CBO9781107415324.004.

PRESS RELEASE: ECB determined ABLV Bank was failing or likely to fail. (2018). European Central Bank. Retrieved from https://www.bankingsupervision.europa.eu/press/pr/date/2018/html/ssm.pr180224.en.html

Register of Market Participants. (2019). Financial Supervision Authority in Estonia. Retrieved from https://www.fi.ee/et/supervised-entities?closed=1\&st[32] $=32 \& s t[29]=29 \& s t[33]=33 \& s t[34]=34$

Regulation 2013/575/EU. (2013). Regulation (EU) No 575/2013 of the European Parliament and of the Council of 26 June 2013 on prudential requirements for credit institutions and investment firms and amending Regulation (EU) No 648/2012. Official Journal of the European Union. European Parliament and the Council, pp. 1-337. Retrieved from https://eur-lex.europa.eu/legalcontent/EN/TXT/PDF/?uri=CELEX:32013R0575\&from=LV.

Rimavičiūtè, S., \& Vilys, M. (2014). ASSESSMENT OF COMPETITION IN THE BANKING SECTOR OF LITHUANIA. Business in XXI century, 6(1), 56-63. doi: 10.3846/mla.2014.08.

Rodriguez-Moreno, M., \& Peña, J. I. (2014). Derivatives Holdings and Systemic Risk in the U.S. Banking Sector', Journal of Banking \& Finance, 45, 84-104. doi: 10.1016/j.jbankfin.2014.03.037.

Rodríguez-Moreno, M., \& Pena, J. I. (2013). Systemic risk measures : The simpler the better? Journal of Banking, 37, 1817-1831. doi: 10.1016/j.jbankfin.2012.07.010

Ross, S.A., Westerfield, R.W., Jaffe, J.F., \& Jordan, B.D. (2011) Core Principles and Applications of Corporate Finance: Global Edition. Third Edition. New York: McGraw-Hill Education 2011.

Skvarciany, V., et al. (2018). Factors influencing a bank's competitive ability: the case of Lithuania and Latvia. Oeconomia copernicana, 9(1), 7-28. doi: 10.24136/oc.2018.001.

Versobank. (2018) Versobank as operating license is revoked. Retrieved from http://www.versobank.com/litsentsist-ilma-eng.html

Yang, F. (2019). The impact of financial development on economic growth in middle-income countries. Journal of International Financial Markets, Institutions and Money, 59(July 2017), 74-89. doi: 10.1016/j.intfin.2018.11.008.

Zheng, Q., \& Song, L. (2018). Dynamic Contagion of Systemic Risks on Global Main Equity Markets Based on Granger Causality Networks. Discrete Dynamics in Nature and Society, 13. doi: https://doi.org/10.1155/2018/9461870. 